\title{
Recorregut de recerca geològica i mineralògica per les comarques del Pallars Jussà i de la Noguera: des de Talarn a Tremp, Suterranya, Sant Salvador de Toló i a Vilanova de Meià
}

Josep Maria Mata-Perelló

Joaquim Sanz Balagué

\section{XARAGALL \\ REVISTA DE CIÈNCIES DE LA CATALUNYA CENTRAL}

n. 8

AGOST 2015 


\title{
RECORREGUT DE RECERCA GEOLÒGICA I MINERALÒGICA PER LES COMARQUES DEL PALLARS JUSSÀ I DE LA NOGUERA: DES DE TALARN A TREMP, SUTERRANYA, SANT SALVADOR DE TOLÓ I A VILANOVA DE MEIÀ
}

\author{
Josep Maria Mata-Perelló \\ Museu de geologia Valentí Masachs, Escola Politècnica Superior d'Enginyeria de Manresa \\ (EPSEM), Universitat Politècnica de Catalunya · BarcelonaTech (UPC), 08272 Manresa, Spain
}

\section{Joaquim Sanz Balagué}

Departament d'Enginyeria Minera i Recursos Naturals (EMRN), Escola Politècnica Superior d'Enginyeria de Manresa (EPSEM), Universitat Politècnica de Catalunya - BarcelonaTech (UPC), 08272 Manresa, Spain

Paraules clau: Sistema Pirinenc, Patrimoni miner

\section{Resum}

Itinerari realitzat el 9 d'agost de 2014. En aquesta ocasió, el recorregut de l'itinerari discorrerà, en la seva quasi totalitat pel Sistema Pirinenc, i més concretament ho farà per la seva Unitat Sudpirinenca Central (també anomenada com a les Serres Exteriors Prepirinenques).

En concret, el recorregut del present itinerari passarà per dos dels seus sectors més representatius; concretament pel Mantell del Montsec (més situat al Sud) i també per alguns indrets del Mantell de la Serra de Sant Mamet, situat al Sud de I'anterior, cap a la fi del recorregut, que veurem de molt a prop.

Així, l'itinerari s'iniciarà dintre del Mantell del Montsec, però les immediacions de la població de Talarn. Després, la major part del recorregut discorrerà per aquest mantell, fins arribar a les immediacions de Vilanova de Meià.

Per altra banda, el recorregut de l'itinerari discorrerà íntegrament per dues úniques comarques: s'iniciarà a la del Pallars Jussà (de la Regió de Tremp), per a finalitzar a la Noguera (de la Regió de Lleida). Concretament, ho farà entre les poblacions de la Talarn i Meià. 


\section{Objectius fonamentals}

Es centraran en els aspectes geològics, geomorfològics i mineralògics que apuntarem a continuació:

1. Estudi de l'estructura materials del Mantell del Montsec (situats dintre dels relleus prepirinencs de la Unitat Sud-pirinenca Central), que es tallaran al llarg del recorregut de tot l'itinerari, entre Talarn i les immediacions de Vilanova de Meià.

2. Estudi i observació dels materials mesozoics (del Juràssic i sobretot del Cretàcic), i del cenozoic (fonamentalment de l'Eocè i de l'Oligocè), que formen part dels relleus del mantell acabats d'esmentar al paràgraf anterior. I, tanmateix dels materials oligocènics postorogènics que ocasionalment els cobreixen.

3. Estudi de l'estructura materials del Mantell de la Serra de Sant Mamet (situats també dintre dels relleus prepirinencs de les Serres Prepirinenques Exteriors), que nosaltres veurem de molt a prop, solament a la darrera aturada.

4. Estudi i observació dels materials mesozoics (del Juràssic i sobretot del Cretàcic), i del cenozoic (fonamentalment de l'Eocè i de l'Oligocè), que formen part dels relleus del Mantell de la Serra de Sant Mamet.

5. Observació de les relacions existents, dintre de la zona per la qual discorre el recorregut de l'itinerari, entre les zones abans esmentades, del Sistema Pirinenc. (concretament entre el Mantell del Montsec i el Mantell de la Serra de Sant Mamet.

6. Reconeixement de diverses mineralitzacions situades al llarg del recorregut del present itinerari.

7. Observació dels diferents indrets relacionats amb el patrimoni geològic que anirem trobant al llarg del recorregut d'aquest itinerari.

8. Observació dels diferents indrets relacionats amb el patrimoni miner, si s'escau, que anem trobant al llarg del recorregut d'aquest itinerari. 


\section{Antecedents}

En relació amb aquest itinerari geològico-mineralògic, existeixen pocs antecedents; de fet, sols farem esment dels següents antecedents nostres: MATA-PERELLÓ (1996, 1999, 2002, 2009, 2011, 2012 y 2014); així com de MATA-PERELLÓ i MONTANÉ (2005 i 2006). Es tracta, en tots els casos, d'itineraris similars al que ara tractarem, i que discorren per aquestes mateixes comarques en la seva major part del recorregut.

Pel que fa a les mineralitzacions que veurem en aquest itinerari, cal dir que també ja estat prèviament descrites per nosaltres mateixos en MATA-PERELLÓ (1991). En aquest treball es fa referència a les mineralitzacions catalanes en general, parlant-se també de les situades al Ilarg d'aquest itinerari; i que es distribueixen tant per la Noguera, com pel Pallars Jussà.

I pel que fa a l'estructura geològica, ens remetérem a RIBA et altri (1976), i a GUIMERÀ et altri (1992). En ambdós treballs, es fa referència a l'estructura geològica dels Països Catalans. Per d'altra banda, també ens cal fer referència de ROSELL (1970); així com de l'IGME (1994).

Finalment, cal dir que tots aquests treballs, es trobaran relacionats, per estricte ordre alfabètic, dintre de l'apartat dedicat a les REFERĖNCIES BIBLIOGRÀFIQUES, al qual es remetem, pel que s'escaigui.

\section{Recorregut de l'itinerari}

Aquest itinerari, s'iniciarà per les immediacions de la població de Talarn, prop d'on es farà una aturada. Tot seguit, per la carretera $C-13$, el recorregut es dirigirà cap a Tremp, fent-se una nova aturada, a la sortida, tot anant cap a llevant per la carretera C- 1412.

Després es recorregut es dirigirà cap a Vilamitjana, des d'on s'anirà cap a Suterranya, tot fent una fillola. En aquest recorregut es farà una nova aturada i després el recorregut continuarà per la carretera $C-1412$, fins a trobar el trencall de la carretera local $L-912$, la qual es dirigeix cap a Sant Salvador de Toló, cap on anirem. Prop d'aquí es farà una nova parada.

Després, el recorregut continuarà cap a llevant (cap el Port de Comiols) per la carretera $L$ 912; però en arribar prop del Mas de Guillem, trobarem per l'esquerra el trencall que es dirigeix cap el Hostal Roig, prop d'aquí farem una nova aturada.

Després el recorregut continuarà per la carretera local $L$ - 913, la qual es dirigeix cap a Vilanova de Meià, entrant així a la Noguera i deixant el Pallars Jussà. En aquest recorregut es faran diverses aturades. 


\section{Advertiments previs}

Com en altres recorreguts de RECERCA GEOLÒGICA I MINERALÒGICA... si es disposa del temps suficient, poden efectuar-se passant per totes les parades i filloles. En cas contrari, recomanem prescindir de les anomenades PARADES - CONDICIONALS.

Per altra banda, cal tenir cura del coneixement de l'estat de conservació d'alguns dels trams dels camins a recórrer. En concret, del que ens ha de conduir des de les immediacions de Sant Salvador de Toló (del Mas de Guillem) a la Collada de l'Hostal Roig, prop de Vilanova de Meià. I també en la rua d'aproximació a la Fabregada o als rentadors de les mines de lignit, prop de Vilanova de Meià.

Per altra banda, i a l'igual que en altres recorreguts semblants, recomanem tenir el màxim de cura i de respecte, entorn de la Natura que ens rodeja.

\section{Descripció de l'itinerari}

Com ja és habitual, farem una sèrie de PARADES (o de ESTACIONS). En cada una d'elles, farem esment del terme municipal on es troben (en el cas de que no quedi clar, al situar la parada), així com del número del MAPA TOPOGRÁFICO NACIONAL (a escala 1:50.000), que indicarem entre parèntesi.

Per altra banda, en cada una de les parades indicarem el nom del municipi, en el qual es troben situades. També indicarem el nombre de la comarca en el qual es troba situada. En aquesta ocasió, utilitzarem els dos següents fulls: 252 (Tremp) i 290 (o d'Isona). Tots aquests fulls, han estat publicats per Instituto Geogràfico y Catastral de España. Tanmateix podem utilitzar es fulls de I'Institut Cartogràfic de Catalunya, dedicats a la comarca del Pallars Jussà i a la de la Noguera.

Així doncs, la relació general ordenada de les aturades que composen aquest itinerari, es el següent:

\subsection{Parada 1 - CONDICIONAL. PUJADA CAP AL POBLE DE TALARN, (terme municipal de Talarn, comarca del Pallars Jussà). (Full 252).}

Del recorregut de l'itinerari l'iniciarem a la Pobla de Segur. Des d'aquí, ens caldrà seguir per la carretera autonòmica $C-13$, anant ara cap a Tremp. Així, després de passar per les immediacions de Salas de Pallars, aviat arribarem al trencall de Talarn, per on caldrà fer una nova aturada, després de recórrer uns $10 \mathrm{Km}$ des de la Pobla de Segur.

En aquest recorregut haurem trobat els afloraments dels materials mesozoics del Cretàcic, els quals formen part dels afloraments més septentrionals del Mantell del Montsec, on estem ara situats.

En aquest indret es pot fer una bona observació dels materials del Garumnià, de tonalitats rogenques. Aquests materials eminentment continentals en aquest indret, constitueixen el trànsit del Cretàcic al Paleocè. 


\subsection{Parada 2. PONT SOBRE EL RIU PALLARESA, CARRTERA C - 1412b, (terme municipal de Tremp, comarca del Pallars Jussà). (Full 252).}

Després de fer la parada anterior, cal continuar cap a Tremp, seguint la carretera autonòmica C - 13. Després, a la sortida de la darrera població esmentada, ens caldrà continuar per la carretera comarcal C-1412b. Per ella es passarà aviat pel pont sobre el Noguera Pallaresa (o riu Pallaresa). Sobre aquest pont farem una nova aturada, a uns $4 \mathrm{Km}$ de I'anteriorment realitzada.

En aquest recorregut, hem anat trobant els materials esmentats a l'aturada anterior, els quals pertanyen als trams finals del Garumnià. Així, per arreu veurem afloraments dels terrenys rogencs, constituïts per calcolutites i per gresos, fonamentalment. Aquests són els materials que apareixen a l'indret de la present aturada

En aquest indret, és un bon lloc per observar la vall de la Pallaresa; així com el seu pas pels voltants de la ciutat de Tremp.

\subsection{Parada 3 CONDICIONAL. ENTRADA A SUTERRANYA, CARRETERA LV - 5111, (Suterranya, és un antic municipi, ara del terme municipal de Tremp, comarca del Pallars Jussà). (Full 290)}

Després de fer la parada anterior, cal continuar cap a Vilamitjana, seguint per la carretera C $1412 \mathrm{~b}$. A uns $2 \mathrm{Km}$ després de sobrepassar el poble anterior, es trobarà un trencall que duu cap a Suterranya (la carretera local LV - 5111). Ens convindrà agafar-lo, per tal de fer una nova parada quasi a l'entrada del poble. Així, haurem recorregut poc més de $6 \mathrm{Km}$, per tal d’arribar fins aquí.

En aquest recorregut, hem estat circulant entre els afloraments dels materials del cretàcic Superior, que formen part del Mantell del Cadí. Aquests són els materials que apareixen a I'indret de la present aturada. Concretament apareixen els nivells de gresos del Maestritxià, els quals es van intentar explotar fa uns anys.

\subsection{Parada 4. ENTRADA A SANT SALVADOR DE TOLÓ, (Sant Salvador de Toló, és un antic municipi, ara del terme municipal de Gavet de la Conca, comarca del Pallars Jussà). (Full 290).}

Després de fer la parada anterior, cal retornar a la carretera comarcal C - 1412b. En trobar-la, caldrà continuar cap a llevant. Poc després de sobrepassar el Riu Abella, trobarem un trencall per la dreta que ens caldrà agafar. Es tracta de la carretera local $L-912$, la qual ens conduirà cap al poble de Sant Salvador de Toló. En arribar-hi, farem una nova aturada, aproximadament a uns $16 \mathrm{Km}$ de la parada anterior.

En aquest recorregut, hem continuat situats dintre del Mantell del Montsec. Per d'altra banda, hem anat trobant afloraments del materials del Cretàcic Superior, fonamentalment del Maestritxià i també dels terrenys del Garumnià, dels nivells que constitueixen el trànsit del Cretàcic al Paleocè.

Aquí, a l'entrada de Sant salvador de Toló (i també pels voltants del poble) afloren els materials rogencs del Garumnià, amb nivells de gresos i de calcolutites, fonamentalment. Aquests materials es fan palesos per arreu, com a l'indret de la present aturada. (fotografia 1). 


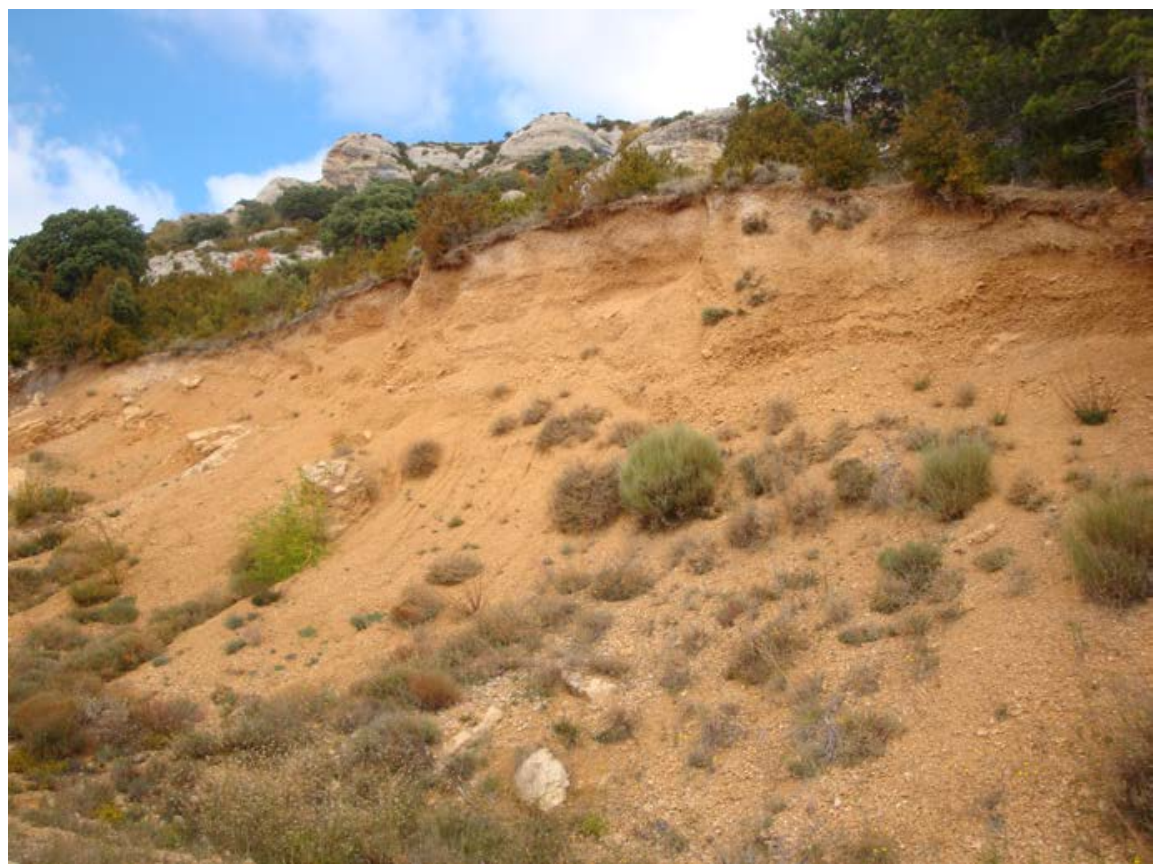

Fotografia 1. Aflorament dels materials del Garumnià, prop de Sant salvador de Toló. Es troben recoberts per terrenys detrítics quaternaris

\subsection{Parada 5. L'HOSTAL ROIG, Sant Salvador de Toló, és un antic municipi, ara del terme de Gavet de la Conca, comarca del Pallars Jussà). (Full 290).}

Després de realitzar la parada anterior, cal travessar el poble de Sant Salvador de Toló. Per tal d'anar cap a Comiols, per la carretera local $L-912$. En arribar a les immediacions del Mas de Guillem, trobarem una pista per la dreta, que condueix cap a l'Hostal Nou i cap a Vilanova de Meià. Després d'arribar a la Collada de l'Hostal Roig ens caldrà fer una fillola per tal d'arribar a l'indret de I'Hostal Roig, utilitzant la carretera local que es dirigeix cap a Sant Martí de la Vall. En arribar a aquest indret, farem una nova aturada, a uns $10 \mathrm{Km}$ de la parada anterior, aproximadament.

La totalitat d'aquest recorregut, I'haurem realitzat entre els afloraments mesozoics cretàcics. En principi, hem anat trobant afloraments dels materials del Cretàcic Superior que hem vist a I'aturada anterior. Ara, prop d'aquí, es fan palesos els materials carbonatats que constitueixen els cims del Montsec.

Aquest indret, per on afloren els materials del Garumnià, per sobre dels materials carbonats acabats d'esmentar, és una interessant divisòria d'aigües: prop d'aquí neix el Riu Boix (tributari del Segre) i també la Barcedana (tributària de la Pallaresa).

Per altra banda, des d'aquest indret, es pot gaudir d'una bona observació, tant cap el Sud com cap el Nord. Així, mirant cap el Nord, es pot veure l'encavalcament del Mantell de Bóixols sobre el Mantell del Montsec, cap els voltants d'Abella de la Conca. 


\subsection{Parada 6. CARRETERA L - 913, IMMEDIACIONS DE LA FONT BLANCA, (terme de Vilanova de Meià, comarca de la Noguera).(Full 290).}

Després de realitzar la parada anterior, cal retornar cap a la Collada de l'Hostal Roig, per tal de baixar cap a Vilanova de Meià, utilitzant la carretera local L - 913. En arribar a les immediacions de la Font Blanca, ens convindrà fer una nova aturada, aproximadament a un \& $\mathrm{Km}$ més avall de la parada anterior.

En aquest recorregut, hem anat trobant afloraments del Cretàcic Superior (fonamentalment del Campanià). Aquests materials han constituït una barrera, a través de la qual s' ha obert pas el riu boix, donant lloc al l'Estret de Pas Nou, que hem travessat per tal d'arribar fins aquí. (fotografia 2).

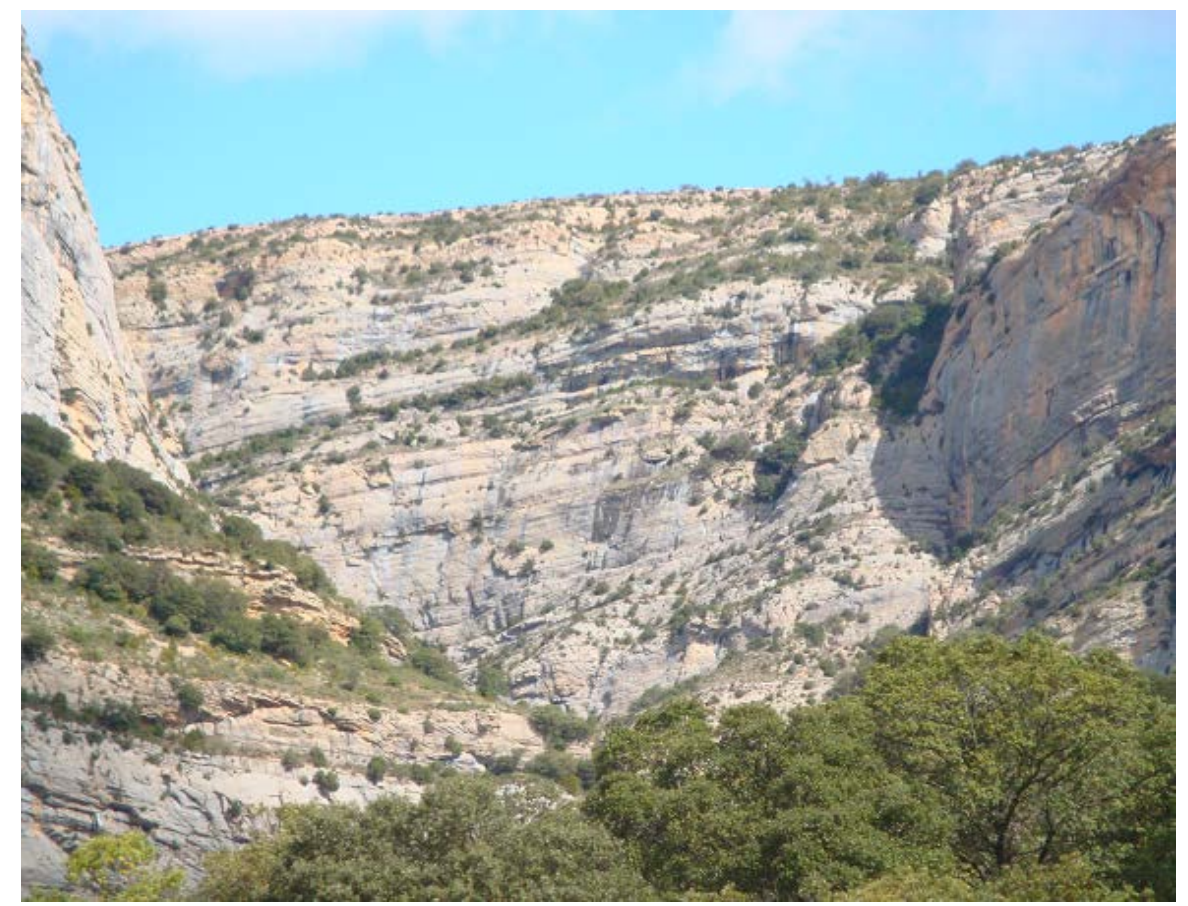

Fotografia 2. Estret de Pas Estret. Aflorament de les calcàries del Campanià. Mantell del Montsec

Després, per sota dels materials anteriors, hem trobat afloraments dels materials lutítics i sorrencs del Cenomanià, els quals es troben per sota del materials carbonatats del Campanià. Precisament, en aquest indret és on es troba la Font Blanca. La font es troba, precisament al contacte entre aquests materials acabats d'esmentar, igual que la propera Font de la Figuera. 


\subsection{Parada 7. IMMEDIACIONS DE LA FABREGADA, (terme municipal de Vilanova de Meià, comarca de la Noguera). (Full 290).}

Després de fer l'aturada anterior, cal fer un breu recorregut cap a llevant, per tal d'arribar al paratge de la Fabregada, per on hi havia un poble medieval. Així, ens caldrà recórrer $1 \mathrm{Km}$,

En aquest recorregut, hem estat circulant pel contacte entre les calcàries del Campanià i les calcolutites i gresos del Cenomanià. Des d'aquest indret es fan palesos els fenòmens karstics entre les calcàries del Campanià. (fotografia 3).

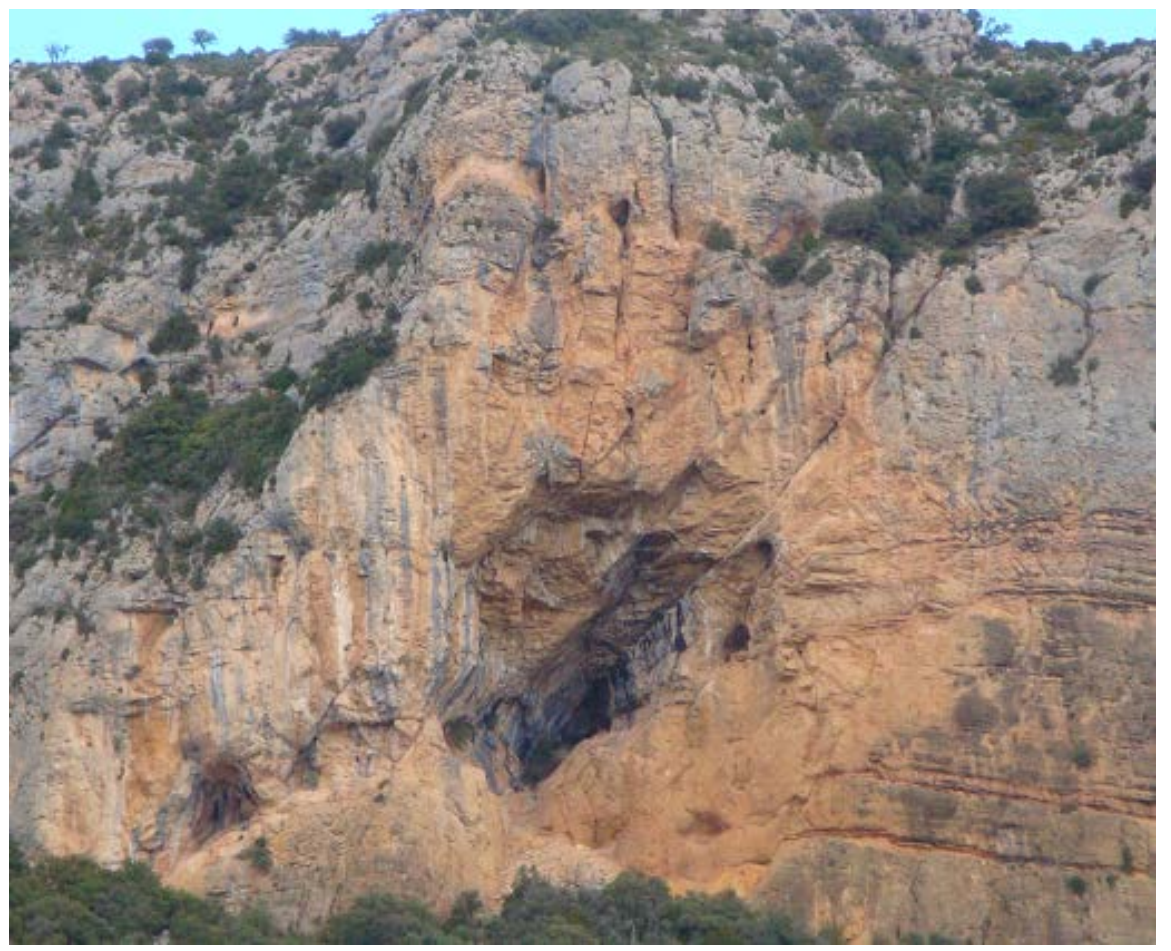

Fotografia 3. Cova de les Monges .La Fabregada. Aflorament de les calcàries del Campanià. Mantell del Montsec

Per altra banda, per sota d'on estem es fan ben palesos uns nivells carbonatats: es tracta de les calcàries de l'Aptià, que trobarem en properes aturades.

També cal dir que prop d'on som ara (a la Fabregada) hi va haver-hi una antiga farga, la qual es troba pràcticament perduda. Tot i així es veuen restes de escòries, així com del canalet de la farga. Els mineres utilitzats s'extreien d'algunes bossades situades entre els materials cretàcics propers. Així mateix, cal dir que creiem que el nom de la Fabregada, procedeix d'aquesta Farga. (fotografia 4). 


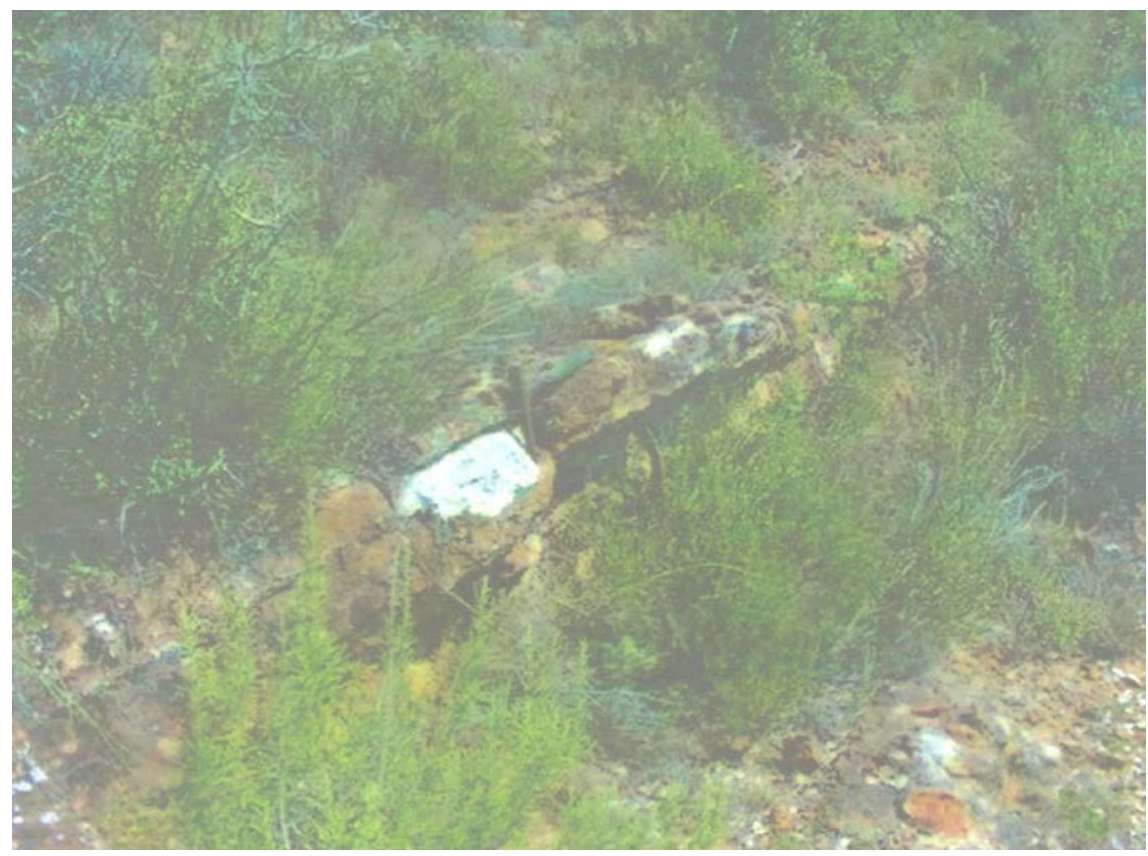

Fotografia 4. Nivells de calcàries ferruginosos. La Fabregada

\subsection{Parada 8. RENTADORS ("LAVADEROS") DE LA MINA DE LIGNIT DELS REGUERS, (terme municipal de Vilanova de Meià, comarca de la Noguera). (Full 290).}

Després de fer l'aturada anterior, cal continuar fent camí per la carretera $L-913$, baixant cap a Vilanova de Meià. En arribar a les immediacions del trencall d'on surt el camí que condueix cap els antics rentadors ("lavaderos") de la Mina de Lignit dels Reguers, podem agafar-lo, per tal d'anar-hi i de una nova aturada, a uns 2 ' $5 \mathrm{Km}$ de la parada anterior.

En aquest recorregut, hem anat trobant afloraments dels materials calcolutítics i sorrencs del Cenomanià. Tot i així, per les immediacions d'on som ara es fan patents uns afloraments de calcàries que pertanyen a l'Aptià. Entre aquests nivells es fan palesos uns nivellets de lignits, visibles prop de la carretera.

Aquests lignits va ésser explotats a diferents indrets, com a la Mina dels Reguers, situada prop de Vilanova de Meià. En un principi el material extret es traginava pel camí de la Cabroa. Tot i així, després es va baixar cap a uns rentadors situats molt prop d'on ara ens trobem. (fotografia 5). 


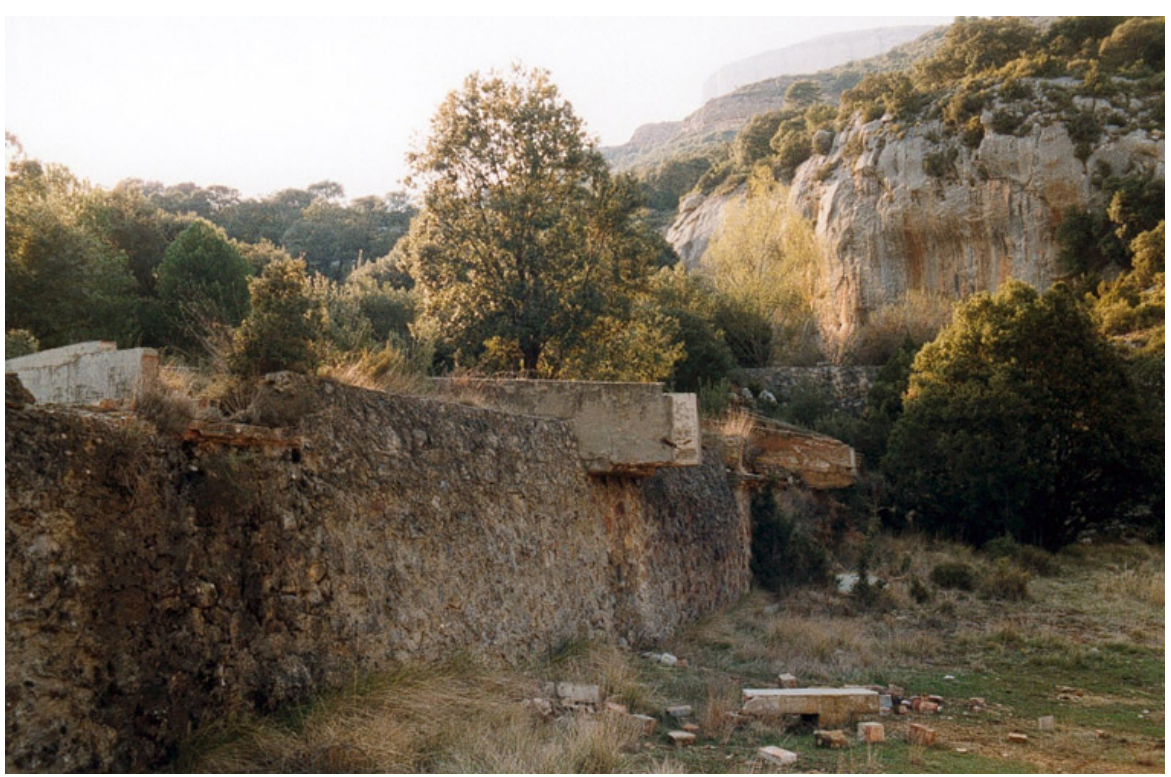

Fotografia 5. Restes dels rentadors ("lavaderos") de les mines de lignit

Tanmateix, prop d'aquest indret escara es poden veure restes del lignit transportat fins aquestes instal-lacions. Finalment, cal dir que tot i el seu mal estat de conservació, aquest indret forma part del Patrimoni Miner de la Noguera.

\subsection{Parada 9. "LA MINA DE LIGNIT DELS ROJOS", CARRTERA L - 913, (terme municipal de Vilanova de Meià, comarca de la Noguera).(Full 290).}

Després de fer l'aturada anterior, cal retornar a la carretera que ens està conduint cap a Vilanova de Meià. En trobar-la, aproximadament a $0^{\prime} 5 \mathrm{Km}$ de la cruillla amb el camí que ens ha conduït a la parada anterior, farem una nova aturada. Així, haurem efectuat un recorregut de poc més de $1 \mathrm{Km}$ des de la parada anterior.

La totalitat d'aquest recorregut I'hem fet entre els afloraments carbonatats dels materials mesozoics de l'Aptià, del Cretàcic Inferior. És a dir: en tot moment ens hem desplaçat dintre del Mantell del Montsec, per on ara estem situats.

Prop del trencall de la parada anterior, entre aquests materials carbonatats, hem trobat petits nivellets de lignits, els quals han estat lleugerament excavats a diferents indrets de la carretera, molt prop d'on ara som.

En aquest indret, durant la passada guerra civil (del Segle XX), per part del Govern Republicà es van fer unes tasques de reconeixement i d'intents d'explotació, les quals van resultar totalment fallides. Precisament el nom popular de la mina, prové d'aquest fet d'haver-se treballat pel Govern Republicà.

De les obres fetes, queda una trinxera a la bora dreta de la carretera, tot baixant cap a Vilanova de Meià. Així, es veu una escombrera i unes tasques de reconeixement fetes entre els nivells carbonatats. (fotografia 6). 


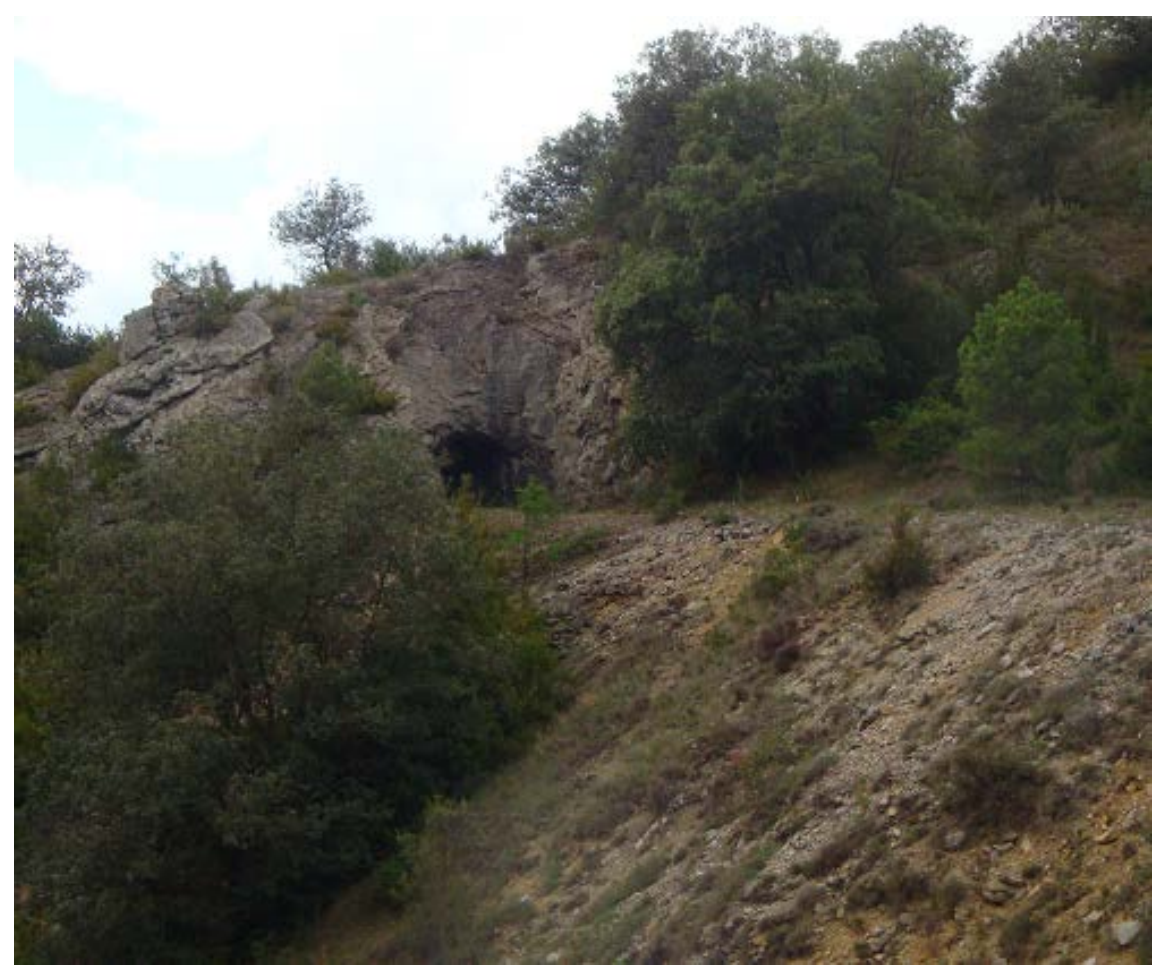

Fotografia 6. Tasques de reconeixement: la Mina de lignit del Rojos. Vilanova de Meià

Tot i així, en aquest indret, hi ha unes interessants cristal-litzacions de PIRITA, descobertes en fer les obres anteriors. Els cubs tenen de 0’ 5 a $1 \mathrm{~cm}$ d'aresta, Tot i ésser força petits, són uns dels més ben desenvolupats a Catalunya. Malgrat això, a l'actualitat costa força de trobar-los.

\subsection{Parada 10. EL PONT DEL RIU BOIX, (terme municipal de Vilanova de Meià, comarca de la Noguera). (Full 290).}

Després de fer l'aturada anterior, cal continuar fent camí per la carretera $L$ - 913, baixant sempre cap a la propera població de Vilanova de Meià. Poc després de fer l'aturada anterior, a menys de 0' $5 \mathrm{Km}$ ens caldrà fer una altra, després d'arribar a l'indret on es va construir un pont i alhora en va fer una gran explanada sobre el riu acanalat.

Com als darrers recorreguts, en aquest tram, hem trobat per arreu, afloraments dels materials carbonatats de I'Aptià, del Cretàcic Inferior. Així, com a les aturades anteriors, estem situats dintre del Mantell del Montsec.

En aquest indret, el riu Boix (o riu de Vilanova), que més o menys estem seguint des de la PARADA $5 \mathrm{~d}$ 'aquest itinerari, es troba canalitzat i discorre sota un pont - túnel, per sota de la carretera $L-913$. Es tracta d'un fet força curiós, ja que per sobre d'aquest pont hi ha una gran explanada, totalment antròpica.

El fet és que durant la República, en intentar obrir-se la mina situada més amunt (la "Mina del Rojos", de la parada anterior), aquí es va fer una explanada i es va canalitzar el riu, per tal d'afavorir l'explotació. Es tracta, doncs d'unes obres realitzades amb motius miners. En conseqüència s' han de de considerar com a Patrimoni Miner, el que realment ho és. Així, és un dels indrets importants del Patrimoni Miner de la Noguera. (fotografia 7). 


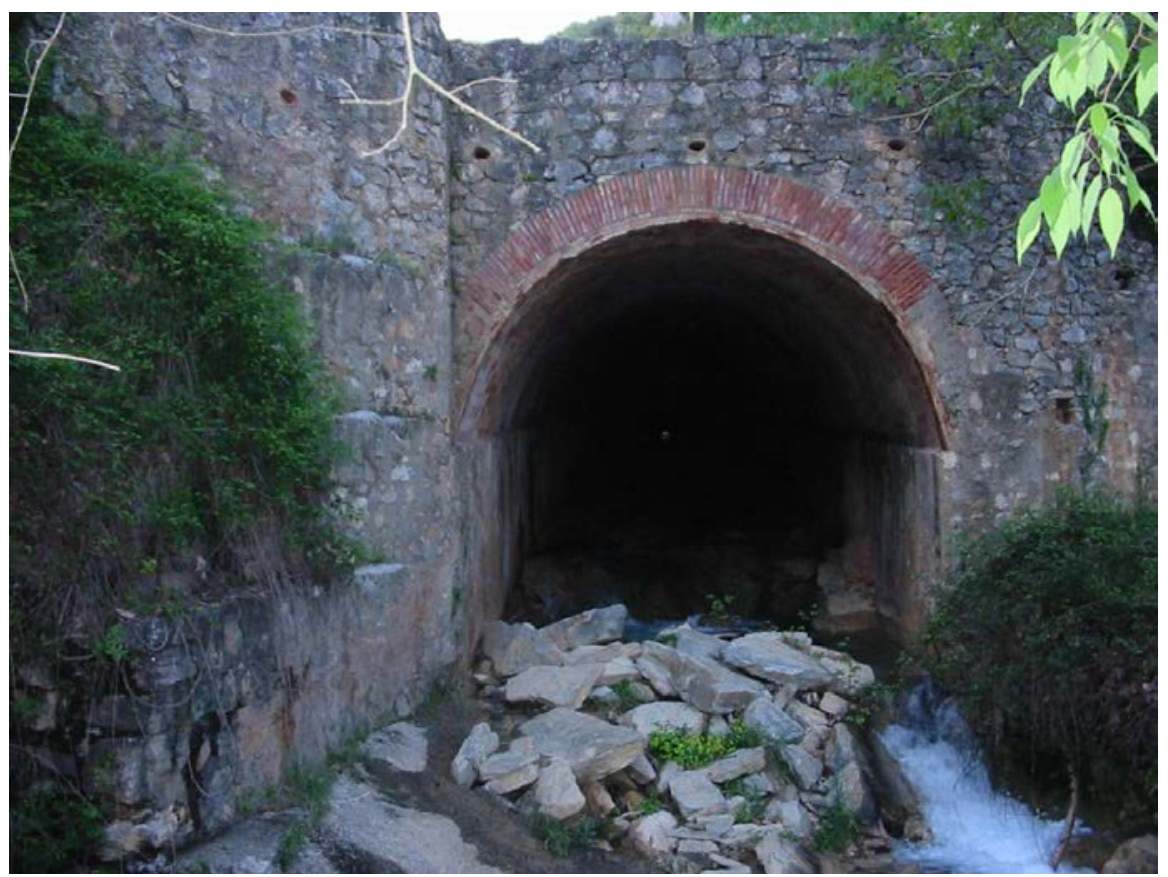

Fotografia 7. Túnel del riu Boix

\subsection{PARADA 11. FORN DE CALÇ, (terme municipal de Vilanova de Meià, comarca de la Noguera). (Full 290).}

Després de realitzar la parada anterior, cal fer un nou i breu recorregut per la carretera $L-913$, anant sempre cap a Vilanova de Meià. En aquest recorregut, després de trobar una petita explotació de les calcàries de l'Aptià, arribarem a una corba, per sobre de la qual es troba un antic Forn de Calç. Aquí farem una nova aturada, a poc més de 0’ $5 \mathrm{Km}$ de l'anterior.

En aquest recorregut, hem continuat trobant afloraments dels materials carbonatats del Cretàcic Inferior, de l'Aptià. Aquests materials, del Maten del Montsec, són els que apareixen a l'indret de la present aturada.

Aquí, entre aquests materials hi ha un interessant Forn de Calç. El qual es troba excavat sobre aquests materials carbonatats. I, precisament, aprofitava aquests materials carbonatats com a matèria prima per a l'obtenció de cal (de OCa). Es tracta d'un element molt important del Patrimoni Miner de la Noguera. (fotografies 8 i 9). 


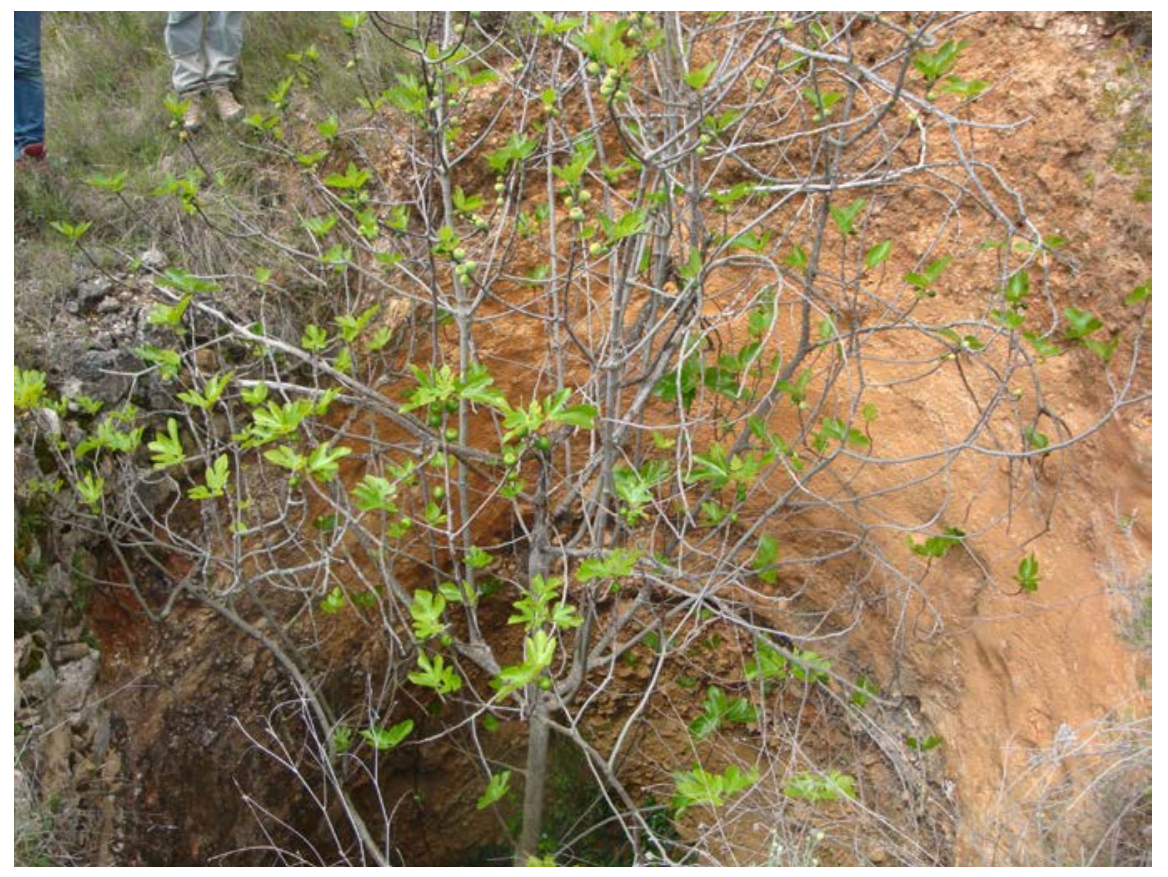

Fotografia 8. Un aspecte del Forn de Calç, des de dalt

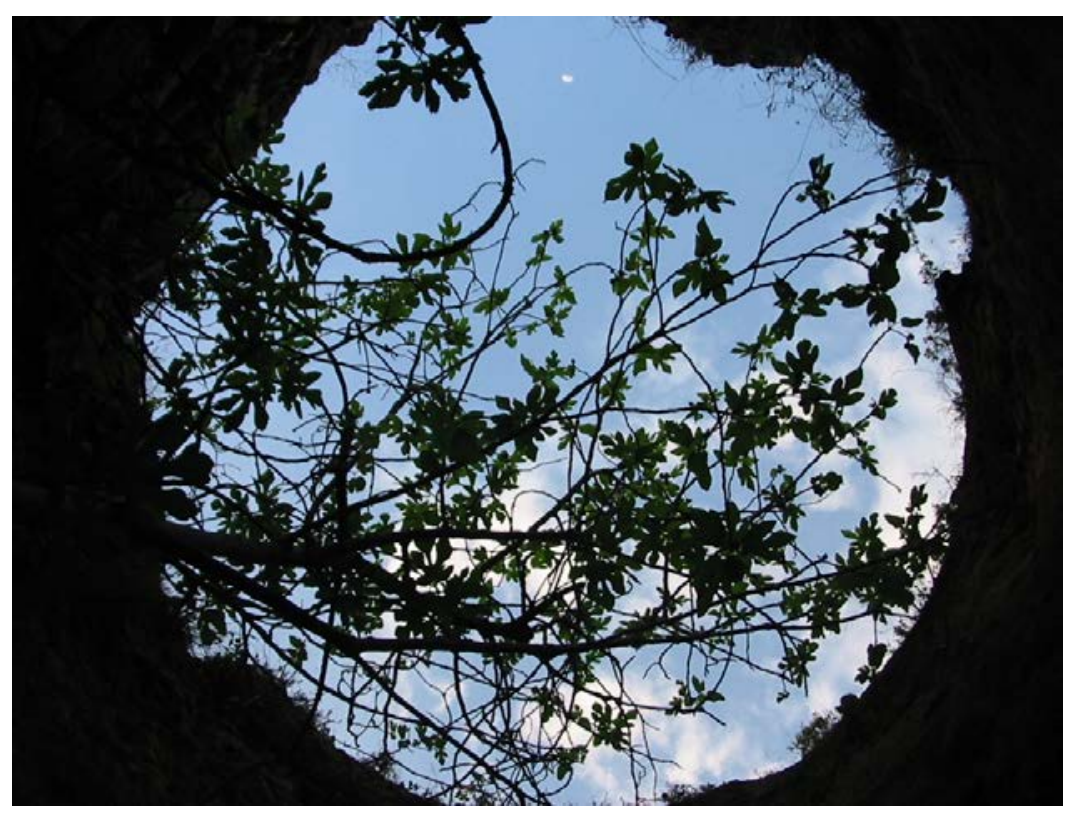

Fotografia 9. Un aspecte del Forn de Calç, des de l'interior 


\subsection{Parada 12. SORTIDA DE VILANOVA DE MEIÀ, CAP A SANTA MARIA DE MEIÀ, CARRETERA LV - 9131, (terme municipal de Vilanova de Meià, comarca de la Noguera). (Full 290).}

Després de realitzar la parada anterior, cal fer breu recorregut per la carretera $L-913$, per tal d'arribar al poble de Vilanova de Meià. Després, cal travessar el poble, per tal d'anar a la cruïlla d'on surt la carretera LV - 9131, la qual es dirigeix cap a Santa Maria de Meià. En aquesta cruïlla farem una nova aturada, la darrera de l'itinerari, a uns $2 \mathrm{Km}$ de I'anterior, aproximadament.

En aquest recorregut, hem travessat l'encavalcament del Mantell del Montsec sobre les Serres Exteriors Pirinenques; concretament sobre els materials cenozoics de l'extrem oriental del Mantell de la Serra de Sant Mamet.

Així, aquest encavalcament dels materials mesozoics del Mantell del Montsec es produeix sobre nivells de calcolutites ocres i de gresos, que pertanyen a la Formació Solsona. Molt sovint, aquests materials es troben recoberts per nivells detrítics de conglomerats de la Formació Berga.

En aquest indret finalitza el recorregut de l'itinerari

\section{Bibliografia}

GUIMERÀ, J. et altri (1992).- Geologia (II), Història Natural dels Països Catalans, Vol.2, 547 pag. Enciclopèdia Catalana, S.A. Barcelona.

IGME (1970).- Mapa Geológico de España, a escala 1.200.000 (Síntesis de la Cartografia existente). Full i memòria no 24, Berga. Inst. Geol. Minero de España. Madrid.

IGME (1994).- Mapa Geológico de España a escala 1:50.000 (Plan Magna). Fulla i Memòria no 252 (Tremp). Inst. GeoMinero y Tecnol. España. Minist. Indústria. Madrid.

MATA - PERELLÓ, J.M. (1991).- Els Minerals de Catalunya. Arxius de la Secció de Ciències, t. XCIII, 442 pag. Institut d’Estudis Catalans. Barcelona.

MATA - PERELLÓ, J.M. (1996c).- Itinerari geològico-mineralògic per la Noguera: des Montclar d'Urgell a Santa Maria de Meià, Inèdit, 13pag. Manresa.

MATA-PERELLÓ, J.M. (1999).- Recerca geològica i mineralògica per les comarques de la Noguera i del Pallars Jussà: des del Pont d'Alentorn a Vilanova de Meià, i des del Pas Nou al congost d’Erinyà. Revista Algeps, n 87, 10 pag. Manresa.

MATA-PERELLÓ, J.M. (2002).- Recerca geològica i mineralògica per la comarca del Pallars Jussà: des del Port de Comiols a Llimiana i a Tremp. Revista Xaragall, sèrie $B, \mathrm{n}^{\circ}$ 194, 8 pag. Manresa.

MATA-PERELLÓ, J.M. (2009).- Recorregut de recerca geològica i mineralògica per la comarca del Pallars Jussà: des de la Pobla de Segur a Tremp i a Isona, tot passant per Basturs, Suterranya i Abella. Inèdit. 8 pàgines. Manresa. 
MATA-PERELLÓ, J.M. (2011).- Recorregut de recerca geològica per la comarca de la Noguera: des de Cubells a la Foradada, Artesa de Segre i a Vilanova de Meià. Inèdit. 12 pàgines Manresa.

MATA-PERELLÓ, J.M. (2012).- Recorregut geològic, geonaturalístic i mineralògic per la comarca de la Noguera: des d'Ager a Sant Oïsme, al Doll, a I'Aiguabarreig i a Vilanova de Meià. Inèdit. 8 pàgines Manresa.

MATA-PERELLÓ, J.M. (2014).- Recorregut de recerca geològica i mineralògica per la comarca del Pallars Jussà: des de la Pobla de Segur, a Tremp i a Isona, tot passant per Talarn, Figuerola d'Orcau, Basturs i Abella de la Conca. Inèdit. 10 pàgines Manresa.

MATA-PERELLÓ, J.M. i MONTANÉ GARCÍA, P. (2005).- Recorregut de recerca geològica i mineralògica per la comarca del Pallars Jussà: des de la pobla de Segur a Tremp i a Isona, tot passant per les immediacions de Basturs, de Suterranya i de Bóixols. Inèdit. 8 pag, Manresa.

MATA-PERELLÓ, J.M. i MONTANÉ GARCÍA, P. (2006).- Recorregut de recerca geològica i mineralògica per la comarca del Pallars Jussà: des de la Pobla de Segur i les Mines de Sossís cap a Tremp i a Isona, tot passant per Basturs, Suterranya, Abella i la Posa. Inèdit. 10pag. Manresa.

RIBA, O. et altri (1976).- Geografia Física dels Països Catalans, Edit. Ketres, 254 pàgines. Barcelona.

ROSELL SANUI, J. (1970).- Explicació del Mapa Geològic, a escala 1:50.000, corresponent al full no 252 (Tremp). Mapa Geológico de España. Inst. Geológico y Minero de España. Madrid. 